Journal of Phycology

October 2017, Volume 53, Issue 5, Pages 1020-1034

http://dx.doi.org/10.1111/ipy.12564

Achimer

http://archimer.ifremer.fr/doc/00392/50345/

(C) 2017 Phycological Society of America

\title{
Contribution of benthic microalgae to the temporal variation in phytoplankton assemblages in a macrotidal system
}

\author{
Hernández Fariñas Tania ${ }^{1,2,{ }^{*}}$, Ribeiro Lourenço ${ }^{1,3}$, Soudant Dominique ${ }^{4,5}$, Belin Catherine ${ }^{4,5}$, \\ Cédric Bacher ${ }^{5}$, Lampert Luis ${ }^{6}$, Barillé Laurent ${ }^{7}$
}

${ }^{1}$ Université de Nantes, Mer-Molécules-Santé EA 2160; Faculté des Sciences et des Techniques; 2 Rue de la Houssinière, BP 9220844322 Nantes, France

2 IFREMER, VIGIES rue de l'îled'Yeu; BP 2110544311 Nantes cedex 03, France

${ }^{3}$ MARE - Marine and Environmental Sciences Centre; Faculdade de Ciências da Universidade de

Lisboa; Campo Grande 1749-016 Lisboa, Portugal

${ }^{4}$ IFREMER VIGIES rue de l'îled'Yeu; BP 2110544311 Nantes cedex 03 ,France

${ }^{5}$ IFREMER; Dyneco/BENTHOS; BP 7029280 Plouzané, France

${ }_{7}^{6}$ IFREMER; Dyneco/Pelagos; BP 7029280 Plouzané, France

${ }^{7}$ Université de Nantes Mer-Molécules-Santé EA 2160; Faculté des Sciences et des Techniques; 2 Rue de la Houssinière, BP 9220844322 Nantes, France

* Corresponding author : Tania Hernández Fariñas, email address :

tania.hernandez-farinas@univ-nantes.fr

\begin{abstract}
:
Suspended marine benthic microalgae in the water column reflect the close relationship between the benthic and pelagic components of coastal ecosystems. In this study, a 12-year phytoplankton timeseries was used to investigate the contribution of benthic microalgae to the pelagic system at a site along the French-Atlantic coast. Furthermore, all taxa identified were allocated into different growth forms in order to study their seasonal patterns. The highest contribution of benthic microalgae was observed during the winter period, reaching up to $60 \%$ of the carbon biomass in the water column. The haptobenthic growth form showed the highest contribution in terms of biomass, dominant in the fallwinter period when the turbidity and the river flow were high. The epipelic growth form did not follow any seasonal pattern. The epiphytic diatom Licmophora was most commonly found during summer. As benthic microalgae were found in the water column throughout the year, the temporal variation detected in the structure of pelagic assemblages in a macrotidal ecosystem was partly derived from the differentiated contribution of several benthic growth forms.
\end{abstract}

Keywords : Co-inertia, dynamic linear models, epipelon, epiphyton, haptobenthos, microphytobenthos growth forms, seasonality, tychoplankton 


\section{INTRODUCTION}

Marine benthic microalgae can be resuspended in the water column under the erosive action of tidal currents or wind-induced waves on bottom sediment (Baillie and Welsh 1980, Admiraal 1984, de Jonge and van Beusekom 1995). This phenomenon contributes to a strong benthic-pelagic coupling (Ubertini et al. 2012), particularly in turbid macrotidal systems where benthic microalgae make a major contribution to the overall primary production (Underwood and Kromkamp 1999). They may represent up to $50 \%$ of the microalgae present in the water column, with significant trophic transfer in food webs (de Jonge and van Beusekom 1992). Benthic microalgae belong to various taxonomic groups, but diatoms are generally dominant (Maclntyre et al. 1996). Moreover, the benthic environment in those areas is not uniform and contains numerous spatial niches which are colonized by well-defined communities, comprised of particular microalgal growth forms, also sometimes termed growth forms (Round 1956, 1965, 1981). In soft-bottom assemblages, diatoms are often divided into two groups: epipsammic species that are attached or almost immobile diatoms growing on sand grains and, therefore, more common in sandflats, and the free-living epipelic species that usually dominate mudflat assemblages (Admiraal 1984). Different growth forms colonize hard substrates or plants, described as epilithic and epiphytic respectively, but their contribution to planktonic assemblages after resuspension processes is seldom considered (Kasim and Mukai 2006). Focusing on growth forms instead of taxonomic composition may allow a clearer assessment of the contribution of the different benthic communities (i.e., epiphyton, epipelon, epipsammon, etc.) to the overall phytoplanktonic assemblages in coastal areas.

This article is protected by copyright. All rights reserved. 
Soft-bottom assemblages exhibit a strong temporal variability in their biomass, and contrasting results have been obtained according to the methods used and the latitude of the ecosystem. However, in northern European estuaries a seasonal pattern with a spring-summer maximum of the chlorophyll- $a$ concentration in the top layers of sediments has been identified using either sediment cores (e.g., de Jonge et al. 2012) or remote-sensing time-series images (van der Wal et al. 2010). This seasonality is generally due to epipelic species, which are associated with the highest biomass compared to epipsammic species (Méléder et al. 2007). Temperature and hydrodynamism appear to be strong drivers of the respective temporal dynamics of these two growth forms (Méléder et al. 2005, Benyoucef et al. 2014). However, when detected in the water column after resuspension, the biomass seasonality of benthic microalgae, more precisely of the epipelon, tends to disappear (de Jonge and van Beusekom 1992, Guarini et al. 2004, Brito et al. 2013), while no information is available for the other growth forms. This clearly suggests that the temporal dynamics of the microphytobenthos, usually detected in their characteristic benthic habitat, become uncoupled or not synchronized when this group is studied as a fraction of the pelagic assemblages. The seasonal signal of the contribution of benthic growth forms to the phytoplankton assemblages has been largely overlooked, and yet it may provide significant clues for trophic studies, water quality assessment or understanding toxic shellfish outbreaks related to phycotoxin-producing benthic species. For instance, several taxa of harmful benthic dinoflagellates have an epiphytic growth form, growing on macroalgae (Hoppenrath et al. 2014).

Time-series of phytoplankton diversity and abundance have recently been exploited to investigate the impact of climate change on the spatial distribution-shift of plankton through the ecological niche approach (Grüner et al. 2011, Irwin et al. 2012) or to analyze shifts in assemblage composition (Klais et al. 2011). Phytoplankton is characterized by a marked seasonality with bloom periods in spring and fall at temperate latitudes (Cloern 1996), but long-term studies have revealed distinct

This article is protected by copyright. All rights reserved. 
patterns between phytoplanktonic groups (Widdicombe et al. 2010). However, these time-series have not been used to investigate the temporal dynamics of the benthic contribution to phytoplanktonic assemblages, and only the work of Guarini et al. (2004) considered this particular approach. Nevertheless, these authors analyzed a five-year survey with a typology that did not include all benthic growth forms.

The main objective of this work is to analyze the seasonal contribution of benthic microalgal growth forms to phytoplankton using a 12-year time-series from the Phytoplankton and Phycotoxin Monitoring Network (REPHY) implemented and managed by the French Research Institute for the Exploitation of the Sea (IFREMER; Gailhard et al. 2002, Hernández Fariñas et al. 2015). The timeseries was first treated with a univariate approach which included an autocorrelation analysis and a Dynamic Linear Model to retrieve the seasonal component of each growth form. The last step was to use a co-inertia analysis as a multivariate approach to link environmental variables to the temporal dynamic of taxonomic units.

\section{MATERIAL AND METHODS}

\section{Study area}

The study was carried out along the French Atlantic coast between 1995 and 2006. The sampling point is located at the north-end of Noirmoutier Island (Fig. 1) in shallow waters (depth approximately 3 to $5 \mathrm{~m}$ ) of the Bourgneuf Bay. This bay, situated south of the Loire estuary has a maximum tidal amplitude of $6 \mathrm{~m}$ during spring tides. The bay extends over a total surface area of $340 \mathrm{~km}^{2}, 100 \mathrm{~km}^{2}$ of which are intertidal areas with large mudflats. Significant aquaculture of the oyster Crassostrea gigas spreads over $10 \mathrm{~km}^{2}$ of the intertidal zone, representing the sixth shellfish production site in the country. The western part of the bay, protected from the Atlantic swell by

This article is protected by copyright. All rights reserved. 
Noirmoutier Island, is also characterized by the presence of seagrass meadows, mainly formed by Zostera noltei (Barillé et al. 2010). The bay is also highly turbid, reaching concentrations of suspended particulate matter of up to $1.5 \mathrm{~g} \cdot \mathrm{L}^{-1}$ over mudflats during spring tides (Gernez et al. 2014).

\section{Phytoplankton datasets}

Sampling was undertaken within the French Phytoplankton and Phycotoxin Monitoring Network (REPHY). Bimonthly samples were collected at sub-surface depth (between 0 and $1 \mathrm{~m}$ ) with a HYDROBIOS sampling bottle $(2.5 \mathrm{~L})$ during high tides and fixed with acid Lugol's solution $\left(1.5 \mathrm{~mL} \cdot \mathrm{L}^{-}\right.$ $\left.{ }^{1}\right)$. Sub-samples of $10 \mathrm{~mL}$ were placed on a sedimentation chamber for at least $8 \mathrm{~h}$. The organisms are then identified and counted using an inverted microscopy (Utermöhl 1958). Within the REPHY identification procedure, all the microalgae with the following characteristic were identified: (i) cell size greater than $20 \mu \mathrm{m}$ or (ii) less than $20 \mu \mathrm{m}$ but forming cell chains or colonies and (iii) harmful or potentially toxic species. Identification was performed at the lowest possible taxonomic level (from class to species). Nevertheless, due to changes in taxonomic classification, species or genera were grouped into taxonomic units in order to guarantee the taxonomic homogeneity of the data over time and between the sampling sites. Hence, groups of species or genera are hereafter referred as taxonomic units. Counts were expressed in number of cells per liter. Microalgal biovolumes were then calculated using French standard for associating a geometric shape to each species (NF EN $16695,2015)$. In the context of this long-term monitoring, no measurement of cell sizes was continuously done. Consequently, microalgal biovolumes were calculated as much as possible using size dimensions done by researchers on French Atlantic coast (see Table S1 in the Supporting Information for further details). Nevertheless, a significant amount of information had to be taken from the HELCOM (Helsinki Commission) Phytoplankton Expert Group in the Baltic Sea (Olenina et al. 2006). For taxonomic units at the genus level, size dimensions were taken from the main species

This article is protected by copyright. All rights reserved. 
found in the Bourgneuf Bay as identified from literature. For each taxonomic unit, a unique median volume was applied to all samples in which this taxon was found. Finally, biovolume (V) conversion to carbon was done using the equation $\mathrm{C}=\mathrm{aV}^{\mathrm{b}}$ where $\mathrm{a}$ and $\mathrm{b}$ coefficients depend on groups (diatoms, dinoflagellates, etc.; Menden-Deuer and Lessard 2000). All analyses were done using data expressed in carbon biomass. Results obtained using abundance data was added as Supplementary material (see Figures S1 - S6 in the Supporting Information).

Each taxonomic unit was associated with a growth form group (Table 1) according to the ecological information given by Round et al. (1990), Tomas (1997) and others. The following growth form definitions were adopted:

- Plankton: strictly planktonic genera

- Tychoplankton: taxa that have a benthic/pelagic cycling regulated by coincidental turbulence (cf. Lincoln 1998)

- Epipsammic: organisms that live in close association (attached or free living) with individual sediment particles (cf. Ribeiro et al. 2013), usually sand grains

- Epipelon: large motile diatoms, that can move freely between sediment particles and typically form biofilms (cf. Herlory et al. 2004, Barnett et al. 2015)

- Epiphyton: organisms living in close association with plants, macrophytes or seagrass

- Haptobenthos: taxa that live closely attached to, or growing on, solid submerged surfaces (Round 1981). In this case, it applies to genera with species that live in different hard substrata (e.g., sand grains, rocks, plants) and, therefore, may include species with different growth forms (cf. Poulíčková et al. 2008).

This article is protected by copyright. All rights reserved. 


\section{Environmental datasets}

Phytoplankton samples were accompanied by measurements of water temperature $\left({ }^{\circ} \mathrm{C}\right)$, salinity, turbidity (Nephelometric Turbidity Unit, NTU) and chlorophyll $a\left(\mu \mathrm{g} \cdot \mathrm{L}^{-1}\right)$. The photosynthetically active radiation (PAR, $\mathrm{W} \cdot \mathrm{m}^{-2}$ ) was obtained with the ARPEGE model (Météo France) and the daily PAR was cumulated over the four days preceding the phytoplankton sampling date. This time-lag was introduced to take into account the preceding conditions which are related to microalgal growth (Sabbe 1993). Additionally, precipitation data (mm, Météo France weather station of Bouguenais, $\left.47.15^{\circ} \mathrm{N}, 1.6^{\circ} \mathrm{W}\right)$, wind speed $\left(\mathrm{m} \cdot \mathrm{s}^{-1}\right)$ and flow $\left(\mathrm{m}^{3} \cdot \mathrm{s}^{-1}\right)$ of the Loire River were added to the analyses. Like for the PAR measurements, daily measures of precipitation and river flow were cumulated over the four days before the phytoplankton sampling date. The median measure of wind speed $\left(\mathrm{m} \cdot \mathrm{s}^{-1}\right)$ was also obtained over these four $\mathrm{d}$.

\section{Statistical analyses}

The first step was to describe the contribution of benthic microalgae to the phytoplankton community. For this, a simple index was defined as the ratio of benthic microalgal carbon biomass to the total microalgal biomass in the sample. The derived index not only reflects the relative contribution of benthic microalgae to the plankton, but is also influenced by the seasonal dynamic of the growth form groups.

The second step was to analyze the time-series to characterize the temporal variation in growth forms. To explore the seasonal dynamics of growth form groups, an autocorrelation analysis was performed (ACF). In the ecological context, this numerical tool is used to bring out periodic fluctuations in the biomass of biological systems. To estimate the ACF, the Pearson correlation coefficient is calculated between pairs of observations separated by a lag $\tau$. For example, given a time-series $Y_{t}$, the correlation coefficient at lag $\tau$ is calculated between pairs of values of $Y_{\mathrm{t}}$ and $Y_{\mathrm{t}-\tau}$.

This article is protected by copyright. All rights reserved. 
The correlation coefficients at different lags are then plotted. In addition to the ACF, a Dynamic Linear Model (DLM) was used to characterize further the seasonal patterns of growth forms. DLMs have several strengths. Firstly, they take into account the temporal structure of the time-series and allow parameters to evolve over time, hence the term "dynamic" (Soudant et al. 1997, Petris et al. 2009). Secondly, DLMs are well tailored for monitoring data characteristics such as missing data, outliers or changes in sampling frequency (Hernández Fariñas et al. 2014). The model used in this study has two components: a local linear trend (polynomial model of second order) and a seasonal component that can evolve over time. Observations considered as outliers can be detected by examining the standardized residuals. Assuming a normal distribution, $95 \%$ of the standardized residuals were within the range \pm 1.96 . Values outside this range were potential outliers. These values were not excluded from the analysis and were treated by an intervention procedure. Thus, they were characterized by a variance greater than for the rest of the time-series observations. The ACFs and the DLMs were based on a fortnightly time-step, representing the bimonthly sampling frequency.

Finally, a co-inertia analysis was used to study the relationship between taxonomic units and environmental data at each sampling station. This is a multivariate method for coupling two tables, i.e., taxonomic unit biomass and quantitative environmental variables. A Monte-Carlo permutation test indicated whether the two structures (environment and "phytoplankton") were significantly related (i.e., if there was a co-structure). For these analyses, carbon data were log-transformed ( $x=$ $\left.\log _{10}[x+1]\right)$ to homogenize variances and environmental data were normalized. Since the PAR measures were available after 1996 this analysis was based on the data between 1996 and 2006 . Computations and graphical representations were carried out using the R software for statistical computing. For DLM and co-inertia analyses, the $\mathrm{dlm}$ (Petris 2010) and ade4 (Dray et al. 2007) packages were used respectively.

This article is protected by copyright. All rights reserved. 
RESULTS

\section{Environmental parameters}

The area has a temperate climate under the influence of Atlantic Ocean waters and is characterized by mild winters and summers (water temperature between 11 and $17.9^{\circ} \mathrm{C}$ ). Salinity ranged between 27.1 and 35.2, with lower values observed between January and March (Fig. 2). The Loire River flow (Fig. 3) has a significant influence on the salinity seasonal cycle: a high negative correlation was found between salinity and river run-off (Spearman correlation of $-0.84, p<0.001$ ). The main river floods were not systematically associated with local precipitation (Fig. 3), since the Loire has a large watershed. The surface-water turbidity also displayed a seasonal cycle with higher values generally above 20 NTU during the winter period. Chlorophyll- $a$ measurements were between 0.5 and $10 \mu \mathrm{g}$. $\mathrm{L}^{-1}$ for $80.7 \%$ of the samples. Median annual microalgal biomass ranged between 6.4 to $19.9 \mathrm{mg} \mathrm{C} \cdot \mathrm{L}^{-}$ ${ }^{1}$ with marked inter-annual variability (Fig. 2).

Benthic microalgae contribution to phytoplankton

Seventy-three taxonomic units were identified between 1995 and 2006, mostly belonging to the diatom (45) and dinoflagellate (21) groups. Other taxonomic units were distributed among the classes Chlorophyceae (2), Dictyochophyceae (1), Raphidophyceae (1), Prasinophyceae (1), Trebouxiophyceae (1) and Cyanophyceae (1). The time-series showed a marked seasonal pattern of the benthic contribution, which was much higher during winter, reaching up to $\sim 60 \%$ in terms of carbon (Fig. 4 ).

The median contribution of the planktonic growth form was the highest observed $\left(8.5 \mu \mathrm{g} \mathrm{C} \cdot \mathrm{L}^{-1} ; \mathrm{Fig}\right.$. 5). For this group, the interquartile ranged from 3.6 to $25.6 \mu \mathrm{g} \cdot \mathrm{L}^{-1}$. Within benthic assemblages, the haptobenthic growth form showed the highest median value $\left(0.7 \mu \mathrm{g} C \cdot \mathrm{L}^{-1}\right)$ followed by the

This article is protected by copyright. All rights reserved. 
epiphytic growth form $\left(0.3 \mu \mathrm{g} C \cdot \mathrm{L}^{-1}\right)$. The epipelic and the tychoplanktonic growth forms represented a median biomass of 0.1 and $0.026 \mu \mathrm{g} \mathrm{C} \cdot \mathrm{L}^{-1}$ respectively (Fig. 5). None of the taxonomic units were considered to be exclusively epipsammic.

The specific contribution of planktonic and benthic growth forms to the total biomass varied through seasons (Table 2). During the fall-winter period planktonic diatoms such as Coscinodiscus-Stellarima (COS), Rhizosolenia (RHI), Thalassiosira-Porosira (THP) and Bellerochea (BEL) had the highest biomass contribution. Benthic diatoms such as Biddulphia (BID), Melosira (MEL) and Grammatophora (GRA) occurred mainly during this period and their median contribution to the biomass fluctuated between 4 and $23 \%$. During the spring-summer period planktonic taxonomic units had the highest biomass contribution with the exception of the benthic genus Biddulphia (BID) and Licmophora (LIC) representing up to $2 \%$ of the biomass.

\section{Seasonal patterns of microalgal growth forms}

The yearly time-series and the corresponding autocorrelation function (ACF) for each of the five growth forms showed differences in periodic variations (Fig. 6). The autocorrelation plot of the planktonic group started with a high correlation coefficient at lag $\tau=1$ (corresponding to two weeks), which slowly decreased and became negative, reaching a maximum negative correlation at lag $\tau=12$. The same behavior, but in the opposite direction, was then observed until a lag time of around one year. Such a pattern is mainly driven by periodic changes in the time-series, which indicates the existence of seasonality.

Within benthic assemblages, the tychoplanktonic growth form showed the most pronounced periodicity and like the planktonic group, this group showed a periodic signal in the autocorrelation function. Periodicity was also detected for the haptobenthic and epiphytic

This article is protected by copyright. All rights reserved. 
groups, although less marked than for the tychoplanktonic group. On the contrary, the ACF of the epipelic growth form rapidly decayed to zero and presented no signs of periodicity.

DLM were subsequently used to characterize further the annual cycle of these growth forms.

Despite the potential variability allowed by the DLM to assess seasonality, the estimated seasonality pattern of four growth forms (planktonic, tychoplanktonic, epiphytic and epipelic) was constant over the years and is therefore represented for just one year (Fig. 7). For the haptobenthic growth form, slight variations in the seasonal component were found from year-to-year. To facilitate the graphical representation and the interpretation of results for the haptobenthic group, a single-year representation is used (see Fig. S1 for the year-to-year variation in the haptobenthic growth form). The planktonic group showed a large seasonal component, with a marked peak in biomass in terms of carbon during the early summer (around June). The temporal contribution of benthic microalgae to the water column varied between growth forms. The tychoplanktonic group exhibited a marked seasonal pattern. It differed strikingly from the phytoplankton as maximum levels of biomass were found during the fall-winter period. This pattern contrasts with the absence of seasonal variation within the epipelic growth form. Concerning the haptobenthic group, the DLM results confirmed the seasonal signal detected by the ACF, but again it was less pronounced than for the tychoplanktonic group. Based on the DLM results, the contribution of haptobenthic organisms in terms of carbon was less important mainly during the spring-summer period. Finally, the epiphytic group showed the highest biomass during the summer period.

Coupling environmental conditions to taxonomic unit abundance

Results from the co-inertia analysis showed the relationship between the environmental conditions and the composition of the microalgae community found in the water column (Fig. 8). The correlation coefficient between both tables (environmental - microalgae) was 0.48 and the Monte-

This article is protected by copyright. All rights reserved. 
Carlo test performed indicated that the co-structure between tables was highly significant $(p=$ 0.001). The first two axes of the co-inertia analysis explained $94.6 \%$ of the variance.

The projection of samples described by the environmental datasets (Fig. 8A) enabled the environmental variables (Fig. 8B) and the occurrence of microalgal taxonomic units (Fig. 8C) to be related on a temporal scale. These sample projections emphasize the seasonal pattern typical of temperate areas (Fig. 8A). During the end of the fall and winter period, the wind speed, river flow and turbidity reached their maxima (Figs. 8, A and B). These variables were opposed on the first axis to the water temperature and PAR measures, whose values were high during the late spring and summer period. The salinity was negatively correlated with turbidity and flow. The maximum concentration of chlorophyll- $a$ was mainly associated with the spring period. Finally, precipitation was positively related to the turbidity and flow, although this variable was represented to a lesser extent on the first and second axes of the analyses.

The taxonomic composition of the microalgae community varied along this temporal gradient of environmental conditions. Planktonic taxa were generally found throughout the year. Tychoplanktonic taxa such as Brockmanniella brockmannii (BROCK), as well as haptobenthic taxa, mainly represented by Melosira (MEL) and Fragilaria (FRA), were highly and positively related to turbidity and river flow variables, characteristic of the winter period. Nevertheless, the relationship between Grammatophora (GRA, haptobenthic) and these environmental conditions was less evident. The analysis also revealed a contrasting difference between the seasonal dynamics of two epiphytic taxonomic units: Licmophora (LIC) was generally found during summer while Toxarium was mainly observed in winter. Finally, epipelic taxa presented low scores on both axes, suggesting their presence throughout the year.

This article is protected by copyright. All rights reserved. 


\section{DISCUSSION}

\section{Benthic microalgae contribution to pelagic systems}

The temporal contribution of benthic microalgae to the water column was investigated in a macrotidal system using a twelve year time-series. Data from the French Phytoplankton and Phycotoxin Monitoring Network (REPHY) were previously analyzed to study the spatio-temporal dynamics of phytoplankton, but the benthic contribution to the pelagic community has rarely been described (Beliaeff et al. 2001, Gailhard et al. 2002). In the present study, the contribution of benthic microalgae to the water column assemblages reached up to $60 \%$ of the total biomass in terms of carbon and $80 \%$ in abundance (see Fig. S2), especially during the winter period when the phytoplankton contribution was lowest. Therefore, the seasonal structure and composition of the phytoplankton community was influenced by benthic taxa inputs. Similar results were observed by Guarini et al. (2004) within two French littoral macrotidal systems (Marennes-Oléron Bay and Aiguillon Bay). To obtain a better insight into this contribution to the water column assemblages, benthic taxa were allocated into different growth forms based on substrate preference and adherence (McIntire and Moore 1977, Round 1981), which enabled their respective seasonal patterns to be discriminated during a long time-series.

In our study, four benthic growth forms were identified as part of the pelagic assemblage. One of them is common in soft-bottom sediments (epipelon), two colonize harder submerged substrates (i.e., epiphyton and haptobenthos) and the fourth (tychoplankton) groups organisms that live mostly in a benthic environment but may also be found in plankton. Nevertheless, it should be kept in mind that, although these groups have long been defined to describe different benthic habitats (cf. Round 1981), there are not always clear boundaries in natural habitats (Pouličková et al. 2008). In this context, the broadly-defined haptobenthic growth form was chosen to allocate taxa that can colonize different substrates, such as the genus Melosira that may be part of the epilithon and the epiphyton.

This article is protected by copyright. All rights reserved. 
In intertidal areas, differences in sediment texture shape the local contribution of growth forms, with muddy sediments favoring the epipelon/tychoplankton groups, while the epipsammon is more commonly found in sandflats (Hamels et al. 1998, Ribeiro et al. 2013). Likewise, coastal areas with seaweed in rocky areas and seagrasses in soft-bottom sediments favor the presence of epiphytic and haptobenthic taxa. The presence of large intertidal flats in the polyhaline reaches of the Elbe and the Scheldt seems to change the water column community structure through an input of resuspended benthic and tychoplanktonic species (Muylaert and Sabbe 1999). Thus, it is expected that the relative contribution of the different growth forms to the pelagic assemblages will also vary locally due to in situ benthic habitat availability. In Bourgneuf Bay, there are large mudflats colonized by epipelic species (Méléder et al. 2005). It was therefore consistent to find epipelic and tychoplanktonic growth forms in the resuspended benthic assemblages of this area. The abundance of resuspended haptobenthic growth forms such as Melosira was more surprising. The latter are probably related to the presence of a large rocky zone with mediolittoral belts of phaeophytes. On the contrary, the epipsammon was conspicuously absent in the water column in spite of the presence of extensive sandflats (Méléder et al. 2007). Substrate availability is therefore not the only factor influencing the presence of benthic species in the water column. An important factor is that epipsammic assemblages are usually dominated by small diatoms (Ribeiro et al. 2013) which cannot be easily seen using the Utermöhl method and would not have been counted given the $20 \mu \mathrm{m}$ minimum length threshold according to REPHY cell count protocol. Furthermore, de Jonge and van Beusekom (1992) demonstrated that in sandflat diatom assemblages, some epipsammic species are less prone to resuspension by water currents than others, while no differentiation was found in mudflat assemblages. The type and strength of attachment seems to be important, which helps explain why the easily resuspended epipelic growth forms were constantly present in the water column. The abundance of hard-bottom haptobenthic species mirrored the seasonal winter increase in turbidity, which seems to indicate that these more firmly-attached forms need strong or even extreme hydrodynamic events (e.g., storms) to be removed from their substrates and become

This article is protected by copyright. All rights reserved. 
suspended in the water column. The presence of some epiphytic taxa in the water column, albeit in lower abundance (e.g., Licmophora), confirms the importance of considering not only sedimentassociated microalgae, but also species living on other substrates.

\section{Seasonal signal of microalgal growth forms}

A striking result of this study is the characterization of different temporal dynamics associated with growth forms. Concerning phytoplankton, the expected spring maximum in chlorophyll $a$ was observed while the maximum biomass in terms of carbon occurred during the late spring-early summer. In temperate areas, this pattern in phytoplankton dynamics is associated with wellidentified seasonal changes in mixing conditions, an increase in nutrient and light availability and grazing (Winder and Cloern 2010). The changes in phytoplankton assemblage structure (Fig. 8) were also typical of a coastal temperate area, with a Coscinodiscus-Skeletonema-Thalassiosira winter assemblage and Rhizosolenia-Chaetoceros-Leptocylindrus spring bloom assemblage (Hernández Fariñas et al. 2014).

Overall, the benthic contribution was higher during the winter period, also an expected result, as the high hydrodynamism occurring during that season is bound to resuspend more benthic microalgae into the water column. This pattern was only observed for the tychoplanktonic and haptobenthic growth forms, but not in the epipelon and the epiphyton. For the latter, this can be related to the disappearance of macrophytes such as intertidal seagrass during winter.

The epipelon is a particularly interesting case because its biomass in the pelagic assemblages was fairly constant throughout the year and did not replicate the typical microphytobenthos biomass seasonal dynamics observed in the mudflats at low tide, which usually has a marked spring/summer increase in temperate intertidal areas (e.g., Underwood and Kromkamp, 1999, Brito et al. 2013), particularly if they are muddier and are colonized by epipelon-dominated assemblages (van der Wal

This article is protected by copyright. All rights reserved. 
et al. 2010). In Bourgneuf Bay, there is a biomass seasonal trend recently detected with MODIS timeseries satellite images (A. Le Rouxel, pers. comm.), with a main peak early spring and a lower one in fall. The epipelic fraction of the assemblages also shows a clear seasonal signal, becoming more abundant or even the dominant growth form during spring-summer to later decrease in numbers during winter, when the higher hydrodynamism favors the epipsammon (Méléder et al. 2007). Moreover, the lighter mud particles and the associated epipelic growth forms are regularly resuspended by tidal currents according to fortnightly cycles with high concentrations every spring tide (Gernez et al. 2014). Actually, semi-diurnal variations in suspended particulate matter and chlorophyll $a$ above mudflats have an order of magnitude equivalent to their seasonal variations (Barille et al. in prep). This process, together with the fact that there are less epipelic cells in the sediment during winter, when the conditions should favor a higher resuspension, explains in part why the epipelon did not show a seasonal pattern of their presence in the pelagic assemblages.

The seasonality of tychoplanktonic growth forms suggests they do not follow a depositionresuspension cycle similar to the epipelon. This is surprising since tychoplankton shares a common habitat with epipelic species, as they can be very abundant in mudflats (Trites et al. 2005), and also have analogous photo-physiological responses (Barnett et al. 2015). However, it should be noted that this group of mostly non-motile, amphibious coastal species are still little-studied (cf. Sabbe et al. 2010). Many of them belong to the Cymatosiraceae and Thalassiosiraceae and are quite small in cell size, usually below $1000 \mu \mathrm{m}^{3}$ or even below $100 \mu \mathrm{m}^{3}$ (cf. Ribeiro et al. 2013), and may have been underestimated during counts in the REPHY dataset. The seasonal signal of tychoplankton was mainly driven by the taxonomic unit Brockmanniella brockmannii and the Rhaphoneidaceae genera Rhaphoneis and Delphineis. The former is found in coastal plankton with higher frequency during winter (Hoppenrath et al. 2009) but it is also common in silty sediments (Trites et al. 2005), while Delphineis and Rhaphoneis are frequently observed in the plankton, attached to sand grains, after

This article is protected by copyright. All rights reserved. 
turbulence episodes (Kraberg et al 2010). Our results suggest that these taxa are mainly resuspended by extreme hydrodynamic events like storms occurring more often during the winter period.

The epiphyton was the only benthic growth form that had its highest biomass in the pelagic assemblages during summer. Licmophora was the most abundant genus and it was mainly observed during summer throughout this 12-year study; Licmophora seems to be the main driver of that growth form seasonal signal, although other epiphytic genera were mostly detected in winter (e.g., Toxarium, Synedra). Licmophora has indeed been frequently reported for the spring/summer months in the temperate areas, usually colonizing filamentous red algae or tube-dwelling diatoms in tidal pools (Honeywill 1998) or the macrophyte Cymodocea nodosa in a Mediterranean coastal lagoon (Belando et al. 2012). The presence of epiphytic diatoms in the water column (Kasim and Mukai 2006) and on the sediments (Facca et al. 2002, Riaux-Gobin and Bourgoin 2002) has been described although the mechanisms responsible for these transfers have not yet been explained. Physical forcing is the most probable cause, although bioturbation by grazers and the senescence of leaves and algal thalli may also be important factors in suspending these benthic species. Differences in colonized substrata, particularly involving macroalgae and seagrasses with their own annual growth cycles, also have an effect on the presence of this benthic group in pelagic assemblages.

The haptobenthos had a similar, if somewhat smaller, seasonal signal to tychoplankton. With their highest biomass during winter, Melosira, along with Fragilaria, were the main drivers of that signal, which was partly attenuated by the higher biomass of Grammatophora during late summer. Haptobenthos is a broadly defined group that covers genera that can be found in different substrates. Several of them are present both in the epilithon and epiphyton (McIntire and Moore 1997). Melosira nummuloides, for example, attaches to any hard substrate and is often found in the neritic plankton during winter (Hendey 1964). Fragilaria and Cocconeis have many species that are

This article is protected by copyright. All rights reserved. 
commonly part of the epipsammon from Bourgneuf Bay (e.g., Méléder et al. 2007), while others are usually found in epilithic and/or epiphytic assemblages (McIntire and Moore 1977), namely on the leaves of the intertidal Zostera noltei (Lebreton et al. 2009). The haptobenthic Grammatophora has also been observed as a common epiphyte of $Z$. noltei leaves in Bourgneuf Bay seagrass beds ( $M$. Poulin, pers. comm.), which has the highest biomass and extension in summer (Barillé et al. 2010). Interestingly, it mirrored the temporal patterns of the epiphytic genus Licmophora and was also a summer-associated taxon (Fig. 8C). The haptobenthos seasonal pattern seems, therefore, to be a compound of the seasonal trends of individual taxonomic units that were grouped together.

\section{Ecological consequences of the resuspension of different growth forms}

The resuspension of microphytobenthos makes a strong contribution to benthic-pelagic coupling (Ubertini et al. 2012), with a well-known trophic contribution of benthic species for primary consumers (de Jonge and van Beusekom 1992, Choy et al. 2009). Some of these consumers are not necessarily benthic dwellers. This is the case of off-bottom cultivated suspension-feeders like oysters (Dubois et al. 2007) and also planktivorous filter-feeders such as the Atlantic anchoveta (Krumme et al. 2009), whose isotopic signature and gut content revealed the assimilation and ingestion, respectively, of benthic microalgae. Kasim and Mukai (2006) showed the importance of benthic diatom assemblages for oyster and clam aquaculture in Japan. In Bourgneuf Bay, the diet of cultivated oysters Crassostrea gigas is characterized by a substantial use of microphytobenthos, with a mean annual value of $27 \%$ estimated from stable isotopes analysis (Decottignies et al. 2007). A stronger influence was detected in winter, consistent with the higher proportion of resuspended benthic species observed in this study. To our knowledge, the winter availability of benthic diatoms for suspension-feeders, notably tychoplanktonic/haptobenthic species, has not been specifically addressed, since studies generally focus on spring growth and summer reproduction. During this period of low phytoplanktonic abundance common to all north European coastal zones, the energy

This article is protected by copyright. All rights reserved. 
gained from food by filter-feeders sometimes hardly balances their basal metabolic costs (AlunnoBruscia et al. 2011). Therefore, the contribution of the benthic fraction to the filter-feeders' diet may play an important role in their survival during the lean periods (fall-winter). Experiments based on suspension-feeders' short-term physiological responses to monospecific diets (Barillé et al. 2003) could be a first step to assess their trophic interest and analyze the role of the different benthic growth forms in coastal food webs.

A second ecological consequence is related to the epiphytic growth forms. In spite of the low abundance of this group, a seasonal signal was detected with a summer maximum. This result is consistent with the previously described temporal dynamics of epiphytes in temperate and tropical areas, which showed seasonality (Vila et al. 2001, Okolodkov et al. 2007). Several benthic dinoflagellates that potentially produce toxins are epiphytic species (Hoppenrath et al. 2014) and can participate in these assemblages. This is the case of Prorocentrum lima, observed as an epiphyte on macroalgae (MacKenzie et al. 2011), which is detected under low abundances in the REPHY network. The resuspension of these species and their transfer through food webs can have a strong impact in shellfish ecosystems, in which cultivated bivalves can accumulate toxins and be responsible for human poisoning events (Hoppenrath et al. 2014). MacKenzie et al. (2011) indicated that the accessibility of toxic cells to elevated rack-cultured oysters was an important factor in assessing the risk of bivalve contamination. This study showed that epiphytes are detected at the water surface during high tides and can therefore potentially reach shellfish cultures located near the sampling point (oysters on racks and mussels on wooden poles). It would be interesting to see if a genus like Licmophora could be an indicator of resuspension events involving co-occurring epiphytic (and epilithic) potentially toxic benthic species.

This article is protected by copyright. All rights reserved. 


\section{CONCLUSIONS}

This study explored the temporal variations in different microalgal growth forms from a 12-year time-series measuring phytoplankton in a macrotidal system. Our results highlight the importance of benthic microalgae in turbid macrotidal systems, particularly in the winter months when the biomass of phytoplankton decreases. In addition to the seasonal signal of the phytoplankton, the temporal variation detected in the structure of pelagic assemblages in the long-time series was partly derived from the contribution of several benthic growth forms. By allocating the different taxonomic units within growth forms, it was possible to determine that this contribution was partly dependent on their specific benthic growth form. In particular, haptobenthic/tychoplanktonic groups were more common in the pelagic assemblage during the fall-winter period under high hydrodynamic conditions, while the epipelic growth forms were present throughout the year, as they were re-suspended by tidal currents at a higher frequency (semi-diurnal and fortnightly cycles) and did not follow a seasonal pattern. Epiphytes were mainly found in summer, coinciding with the seasonal dynamics of large intertidal seagrass beds.

\section{ACKNOWLEDGEMENTS}

We would like to thanks the many people involved in the REPHY monitoring network and other supporting programs. We address special thanks to Nadine Neaud-Masson for her numerous advices, especially during the process of gathering information concerning the biovolume of taxonomic units. This research is part of a PhD Thesis co-funded by the Fondation de France and the IFREMER.

This article is protected by copyright. All rights reserved. 


\section{REFERENCES}

Admiraal, W. 1984. The ecology of estuarine sediment-inhabiting diatoms. Prog. Phycol. Res. 3:269322.

Alunno-Bruscia, M., Bourlès, Y., Maurer, D., Robert, S., Mazurié, J., Gangnery, A., Goulletquer, P., Pouvreau, S. 2011. A single bio-energetics growth and reproduction model for the oyster Crassostrea gigas in six Atlantic ecosystems. J. Sea Res. 66:340-8.

Baillie, P.W. \& Welsh, B.L. 1980. The effect of tidal resuspension on the distribution of intertidal epipelic algae in an estuary. Estuar. Coast. Mar. Sci. 10:165-80.

Barillé, L., Haure, J., Pales-Espinosa, E. \& Morançais, M. 2003. Finding new diatoms for intensive rearing of the pacific oyster (Crassostrea gigas): energy budget as a selective tool. Aquaculture 217:501-14.

Barillé, L., Robin, M., Harin, N., Bargain, A. \& Launeau, P. 2010. Increase in seagrass distribution at Bourgneuf Bay (France) detected by spatial remote sensing. Aquat. Bot. 92:185-94.

Barnett, A., Méléder, V., Blommaert, L., Lepetit, B., Gaudin, P., Vyverman, W., Sabbe, K., Dupuy, C. \& Lavaud, J. 2015. Growth form defines physiological photoprotective capacity in intertidal benthic diatoms. ISME J. 9:32-45.

This article is protected by copyright. All rights reserved. 
Belando. M.D., Marin A. \& Aboal M. 2012. Licmophora species from a Mediterranean hypersaline coastal lagoon (Mar Menor, Murcia, SE Spain). Nova Hedwigia 141:275-288.

Beliaeff, B., Gros, P., Belin, C., Raffin, B., Gailhard, I. \& Durbec, J. P. 2001. "Phytoplankton events" in French coastal waters during 1987-1997. Oceanol. Acta. 24:425-33.

Benyoucef, I., Blandin, E., Lerouxel, A., Jesus, B., Rosa, P., Méléder, V., Launeau, P. et al. 2014. Microphytobenthos interannual variations in a north-European estuary (Loire estuary, France) detected by visible-infrared multispectral remote sensing. Estuar. Coast. Shelf Sci. 136:43-52.

Brito, A.C., Benyoucef, I., Jesus, B., Brotas, V., Gernez, P., Mendes, C.R., Launeau, P., Peixe Dias, M., \& Barillé, L. 2013. Seasonality of microphytobenthos revealed by remote-sensing in a South European estuary. Cont. Shelf Res. 66:83-91.

Choy, E. J., Richard, P., Kim, K. R. \& Kang, C. K. 2009. Quantifying the trophic base for benthic secondary production in the Nakdong River estuary of Korea using stable $\mathrm{C}$ and $\mathrm{N}$ isotopes. J. Exp. Mar. Biol. Ecol. 382:18-26.

Cloern, J. E. 1996. Phytoplankton bloom dynamics in coastal ecosystems: A review with some general lessons from sustained investigation of San Francisco Bay, California. Rev. Geophys. 34:12768.

This article is protected by copyright. All rights reserved. 
de Jonge, V. N., de Boer, W. F., de Jong, D. J. \& Brauer, V. S. 2012. Long-term mean annual microphytobenthos chlorophyll a variation correlates with air temperature. Mar. Ecol. Prog. Ser. 468:43-56.

de Jonge, V. N. \& van Beusekom, J. E. E. 1995. Wind- and tide-induced resuspension of sediment and microphytobenthos from tidal flats in the Ems Estuary. Limnol. Oceanogr.40:766-78.

de Jonge, V.N. \& van Beusekom, J.E.E. 1992. Contribution of resuspended microphytobenthos to total phytoplankton in the EMS estuary and its possible role for grazers. Neth. J. Sea Res. 30:91-105.

Decottignies, P., Beninger, P.G., Rincé, Y., Robins, R.J. \& Riera, P. 2007. Exploitation of natural food sources by two sympatric, invasive suspension-feeders: Crassostrea gigas and Crepidula fornicata. Mar. Ecol. Prog. Ser. 334:179-92.

Dray, S., Dufour, A.B. \& Chessel, D. 2007. The ade4 Package-II: Two-table and K-table Methods. $R$ News. 7:47-52.

Dubois, S., Orvain, F., Marin Leal, J.C., Ropert, M. \& Lefebvre, S. 2007. Small-scale spatial variability of food partitioning between cultivated oysters and associated suspension-feeding species, as revealed by stable isotopes. Mar. Ecol. Prog. Ser. 336:151-60.

This article is protected by copyright. All rights reserved. 
Facca, C., Sfriso, A. \& Socal, G. 2002. Temporal and Spatial Distribution of Diatoms in the Surface Sediments of the Venice Lagoon. Bot. Mar. 45:170-83.

Gailhard, I., Gros, P., Durbec, J.P., Beliaeff, B., Belin, C., Nézan, E. \& Lassus, P. 2002. Variability patterns of microphytoplankton communities along the French coasts. Mar. Ecol. Prog. Ser. 242:3950.

Gernez, P., Barillé, L., Lerouxel, A., Mazeran, C., Lucas, A. \& Doxaran, D. 2014. Remote sensing of suspended particulate matter in turbid oyster-farming ecosystems. J. Geophys. Res. Oceans. 119:7277-94.

Grüner, N., Gebühr, C., Boersma, M., Feudel, U., Wiltshire, K.H. \& Freund, J.A. 2011. Reconstructing the realized niche of phytoplankton species from environmental data: fitness versus abundance approach. Limnol. Oceanogr. Methods. 9:432-42.

Guarini, J. M., Gros, P., Blanchard, G., Richard, P. \& Fillon, A. 2004. Benthic contribution to pelagic microalgal communities in two semi-enclosed, European-type littoral ecosystems (Marennes-Oléron Bay and Aiguillon Bay, France). J. Sea Res. 52:241-58.

Hamels, I., Sabbe, K., Muylaert, K., Barranguet, C., Lucas, C., Herman, P. \& Vyverman, W. 1998. Organisation of microbenthic communities in intertidal Estuarine flats, a case study from the Molenplaat (Westerschelde estuary, The Netherlands). Eur. J. Protistol. 34:308-20.

This article is protected by copyright. All rights reserved. 
Hendey, N.I. 1964. An Introductory Account of the Smaller Algae of British Coastal Waters. Part V. Bacillariophyceae (Diatoms). J. Mar. Biol. Assoc. UK 45:798-798.

Herlory, O., Guarini, J. M., Richard, P. \& Blanchard, G.F. 2004. Microstructure of microphytobenthic biofilm and its spatio-temporal dynamics in an intertidal mudflat (Aiguillon Bay, France). Mar. Ecol. Prog. Ser. 282:33-44.

Hernández Fariñas, T., Soudant, D., Barillé, L., Belin, C., Lefebvre, A. \& Bacher, C. 2014. Temporal changes in the phytoplankton community along the French coast of the eastern English Channel and the southern Bight of the North Sea. ICES J. Mar. Sci. J. Cons. 71:821-33.

Hernández Fariñas, T., Bacher, C., Soudant, D., Belin, C. \& Barillé, L. 2015. Assessing phytoplankton realized niches using a French national phytoplankton monitoring network. Estuar. Coast. Shelf Sci. 159:15-27.

Honeywill, C. 1998. A Study of British Licmophora Species and a Discussion of Its Morphological Features. Diatom Res. 13:221-71.

Hoppenrath, M., Elbrächter, M. \& Drebes, G. 2009. Marine Phytoplankton. Selected microphytoplankton species from the North Sea around Helgoland and Sylt. Schweizerbart Science Publishers, Stuttgart, Germany, 264 pp.

This article is protected by copyright. All rights reserved. 
Hoppenrath, M., Murray, S.A., Chomérat, N. \& Horiguchi, T. 2014. Marine benthic dinoflagellates unveiling their worldwide biodiversity. Schweizerbart Science Publishers, Stuttgart, Germany, 276 pp.

Irwin, A.J., Nelles, A.M. \& Finkel, Z.V. 2012. Phytoplankton niches estimated from field data. Limnol. Oceanogr. 57:787-97.

Kasim, M. \& Mukai, H. 2006. Contribution of benthic and epiphytic diatoms to clam and oyster production in the Akkeshi-ko estuary. J. Oceanogr. 62:267-81.

Klais, R., Tamminen, T., Kremp, A., Spilling, K. \& Olli, K. 2011. Decadal-Scale Changes of Dinoflagellates and Diatoms in the Anomalous Baltic Sea Spring Bloom. PLOS ONE. 6:e21567.

Kraberg, A., Dürselen, C. D. \& Baumann, M. 2010. Coastal Phytoplankton: Photo Guide for Northern European Seas. Pfeil, Munich, Germany, 204 pp.

Krumme, U., Keuthen, H., Barletta, M., Saint-Paul, U. \& Villwock, W. 2009. Resuspended intertidal microphytobenthos as major diet component of planktivorous atlantic Anchoveta Cetengraulis edentulus (Engraulidae) from Equatorial mangrove creeks. Ecotropica 14:121-8.

This article is protected by copyright. All rights reserved. 
Lebreton, B., Richard, P., Radenac, G., Bordes, M., Bréret, M., Arnaud, C., Mornet, F. et al. 2009. Are epiphytes a significant component of intertidal Zostera noltii beds? Aquat. Bot. 91:82-90.

Lincoln, R.J. 1998. A Dictionary of Ecology, Evolution and Systematics. Cambridge University Press, $361 \mathrm{pp}$.

Maclntyre, H.L., Geider, R.J. \& Miller, D.C. 1996. Microphytobenthos: The ecological role of the "secret garden" of unvegetated, shallow-water marine habitats. I. Distribution, abundance and primary production. Estuaries 19:186-201.

Menden-Deuer, S., Lessard, E.J. 2000. Carbon to volume relationships for dinoflagellates, diatoms, and other protist plankton. Limnol. Oceanogr. 45: 569-579.

MacKenzie, L.A., Selwood, A.I., McNabb, P. \& Rhodes, L. 2011. Benthic dinoflagellate toxins in two warm-temperate estuaries: Rangaunu and Parengarenga Harbours, Northland, New Zealand. Harmful Algae 10:559-66.

McIntire, C.D. \& Moore, W.W. 1977. Marine littoral diatoms: ecological considerations. In Werner, D. [Ed.] The Biology of Diatoms. Bot. Monogr. University of California Press, Berkeley, pp 333-371.

This article is protected by copyright. All rights reserved. 
Méléder, V., Barillé, L., Rincé, Y., Moranais, M., Rosa, P. \& Gaudin, P. 2005. Spatio-temporal changes in microphytobenthos structure analysed by pigment composition in a macrotidal flat (Bourgneuf Bay, France). Mar. Ecol. Prog. Ser. 297:83-99.

Méléder, V., Rincé, Y., Barillé, L., Gaudin, P. \& Rosa, P. 2007. Spatiotemporal changes in microphytobenthos assemblages in a macrotidal flat (Bourgneuf Bay, France). J. Phycol. 43:1177-90.

Muylaert, K. \& Sabbe, K. 1999. Spring phytoplankton assemblages in and around the maximum turbidity zone of the estuaries of the Elbe (Germany), the Schelde (Belgium/The Netherlands) and the Gironde (France). J. Mar. Syst. 22:133-49.

NF EN 16695. 2015. Norme française. Qualité de l'eau. Lignes directrices pour l'estimation du biovolume des microalgues. Ed. Association Française de Normalisation (AFNOR). 104 pp.

Olenina, I., Hajdu, S., Edler, L., Andersson, A., Wasmund, N., Busch, S., Göbel, J., Gromisz, S., Huseby, S., Huttunen, M., Jaanus, A., Kokkonen, P., Ledaine, I. and Niemkiewicz, E. 2006. Biovolumes and size-classes of phytoplankton in the Baltic Sea HELCOM Balt. Sea Environ. Proc. No. 106, 144 pp.

Okolodkov, Y.B., Campos Bautista, G., Gárate-Lizárraga, I., González-González, J.A.G., Hoppenrath, M. \& Arenas, V. 2007. Seasonal changes of benthic and epiphytic dinoflagellates in the Veracruz reef zone, Gulf of Mexico. Aquat. Microb. Ecol. 47:223-37.

This article is protected by copyright. All rights reserved. 
Petris, G. 2010. An R Package for Dynamic Linear Models. J. Stat. Softw.36:1-16.

Petris, G., Campagnoli, P. \& Petrone 2009. Dynamic Linear Models with R. Springer-Verlag, New York, New York, 252 pp.

Poulíčková,A., Hašler, P., Lysáková, M., \& Spears, B. 2008. The ecology of freshwater epipelic algae: an update. Phycologia 47: 437-450.

Riaux-Gobin, C. \& Bourgoin, P. 2002. Microphytobenthos biomass at Kerguelen's Land (Subantarctic Indian Ocean): repartition and variability during austral summers. J. Mar. Syst. 32:295-306.

Ribeiro, L., Brotas, V., Rincé, Y. \& Jesus, B. 2013. Structure and diversity of intertidal benthic diatom assemblages in contrasting shores: a case study from the Tagus estuary. J. Phycol. 49:258-70.

Round, F. E. 1956. A note on some communities of the littoral zone of lakes. Arch. Hydrobiol. 52: 398-405.

Round, F. E. 1965. The epipsammon; a relatively unknown freshwater algal association. Brit. Phycol. Bull. 2:456-462.

Round, F.E. 1981. The ecology of algae. Cambridge University Press, 653 pp.

This article is protected by copyright. All rights reserved. 
Round, F.E., Crawford, R.M. \& Mann, D.G. 1990. Diatoms: Biology and Morphology of the Genera. Cambridge University Press, 768 pp.

Sabbe, K. 1993. Short-term fluctuations in benthic diatom numbers on an intertidal sandflat in the Westerschelde estuary (Zeeland, The Netherlands). Hydrobiologia 269-270:275-84.

Sabbe, K., Vanelslander, B., Ribeiro, L., Witkowski, A., Muylaert, K. \& Vyverman, W. 2010. A new genus, Pierrecomperia Gen. Nov.: a new species and two new combinations in the marine diatom family Cymatosiraceae. Vie Milieu-Life Environ. 60:243-56.

Soudant, D., Beliaeff, B. \& Thomas, G. 1997. Dynamic linear bayesian models in phytoplankton ecology. Ecol. Model. 99:161-9.

Tomas, C.R. 1997. Identifying Marine Phytoplankton. Academic Press, 858 pp.

Trites, M., Kaczmarska, I., Ehrman, J.M., Hicklin, P.W. \& Ollerhead, J. 2005. Diatoms from two macrotidal mudflats in Chignecto Bay, Upper Bay of Fundy, New Brunswick, Canada. Hydrobiologia 544:299-319.

Ubertini, M., Lefebvre, S., Gangnery, A., Grangeré, K., Gendre, R.L. \& Orvain, F. 2012. Spatial variability of benthic-pelagic coupling in an estuary ecosystem: consequences for microphytobenthos resuspension phenomenon. PLOS ONE 7:e44155.

This article is protected by copyright. All rights reserved. 
Underwood, G.J.C. \& Kromkamp, J. 1999. Primary production by phytoplankton and

microphytobenthos in estuaries. In Nedwell, D.B. \& Raffaelli, D.G. [Eds.] Estuaries. Advances in

Ecological Research. Academic Press, pp. 93-153.

Utermöhl, H. 1958. Zur Vervollkommnung der quantitativen Phytoplankton-Methodik. Mitt Int. Ver. Theor. Angew. Limnol. 9:1-38.

van der Wal, D., Dool, A.W. den \& Herman, P.M.J. 2010. Spatial synchrony in intertidal benthic algal biomass in temperate coastal and estuarine ecosystems. Ecosystems 13:338-51.

Vila, M., Garcés, E. \& Masó, M. 2001. Potentially toxic epiphytic dinoflagellate assemblages on macroalgae in the NW Mediterranean. Aquat. Microb. Ecol. 26:51-60.

Widdicombe, C.E., Eloire, D., Harbour, D., Harris, R.P. \& Somerfield, P.J. 2010. Long-term phytoplankton community dynamics in the Western English Channel. J. Plankton Res. 32:643-55.

Winder, M. \& Cloern, J.E. 2010. The annual cycles of phytoplankton biomass. Philos. Trans. R. Soc. B Biol. Sci. 365:3215-26.

This article is protected by copyright. All rights reserved. 
Table 1: Principal taxonomic units of microalgae identified in the water column, ranked by family and their growth forms.

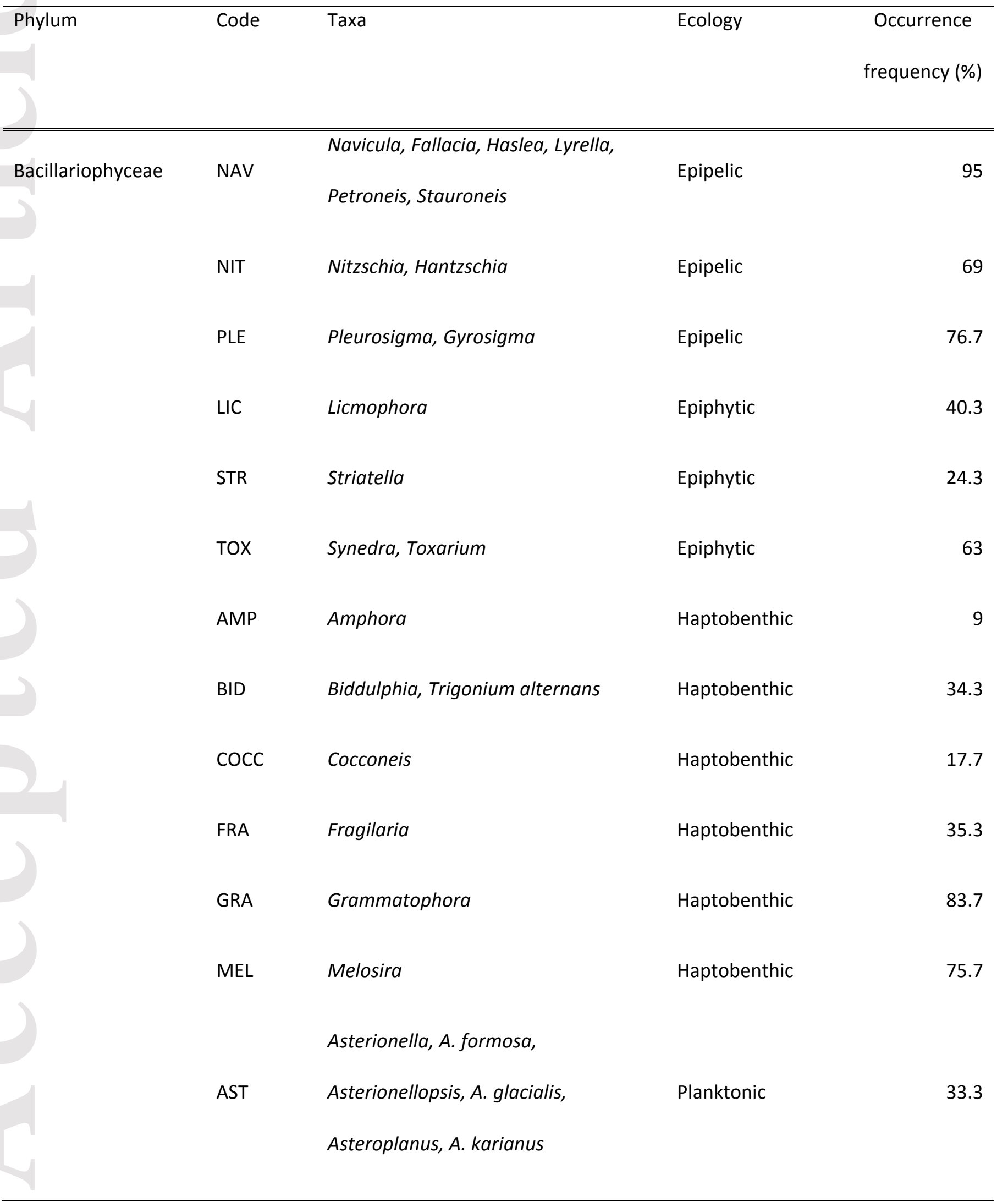

This article is protected by copyright. All rights reserved. 
Chaetoceros, C. curvisetus, C. debilis,

$\mathrm{CHA}$

C. pseudocurvisetus, $C$. danicus, $C$ Planktonic

socialis, C. socialis f. radians

$\cos$

Coscinodiscus, Stellarima

Planktonic

DIT

Ditylum

Planktonic

EUC

Eucampia, Climacodium

Planktonic

GUI

Guinardia, G. delicatula, G. striata

Planktonic

HEL

Helicotheca

Planktonic

LAU

Lauderia, Schroederella

Planktonic

Leptocylindrus, L. danicus, L. curvatus, LEP L. minimus

Planktonic

Pseudo-nitzschia, P. delicatissima, $P$.

PSE

pseudodelicatissima, P. seriata

Planktonic

Proboscia indica, Rhizosolenia, $R$.

$\mathrm{RHI}$ imbricata, R. styliformis, R. setigera, $R$. Planktonic setigera f. pungens

THL

Thalassionema, T. nitzschioides,

Planktonic

This article is protected by copyright. All rights reserved. 
Thalassiothrix, Lioloma

Thalassiosira, T. levanderi, T. minima,

THP

Planktonic

Porosira

BROCK Brockmanniella brockmanni

Tychoplanktonic

54.7

NITL Nitzschia longissima

Tychoplanktonic

50.3

RHA

Rhaphoneis, Delphineis

Tychoplanktonic

Dinophyceae

ALE

Alexandrium, A. minutum

Planktonic

81.3

Ceratium, C. tripos, Tripos furca, $T$.

CEI

fusus, T. lineatus, T. minutus

Planktonic

Dinophysis, D. acuminata, D. acuta, D.

DIN

caudata, D. sacculus

Planktonic

Gymnodinium, Gyrodinium,

GYM

Gyrodinium spirale

Planktonic

KAR

Karenia mikimotoi

Planktonic

KAT

Katodinium

Planktonic

POL

Polykrikos

Planktonic

Prorocentrum, $P$. balticum, $P$.

PRO cordatum, P. micans, $P$. arcuatum, $P$. Planktonic gibbosum

PRP

Peridinium quinquecorne,

Planktonic

This article is protected by copyright. All rights reserved. 
Scrippsiella, Ensiculifera,

Pentapharsodinium, Bysmatrum

Chlorophyceae

PED

Pediastrum

SCE

Scenedesmus

Dictyocha

Chlorophyceae

Dictyochophyceae

DIC
Planktonic

Planktonic

Planktonic

Planktonic

Table 2: Seasonal contribution (in percentage) of the main taxa to the phytoplankton carbon biomass. Median, lower and upper quartiles are indicated. Bold labels indicates benthic growth forms. See Table 1 for taxa codes and associated growth forms. DJF (December, January, February), MAM (March, April, May), JJA (June, July, August), SON (September, October, November).

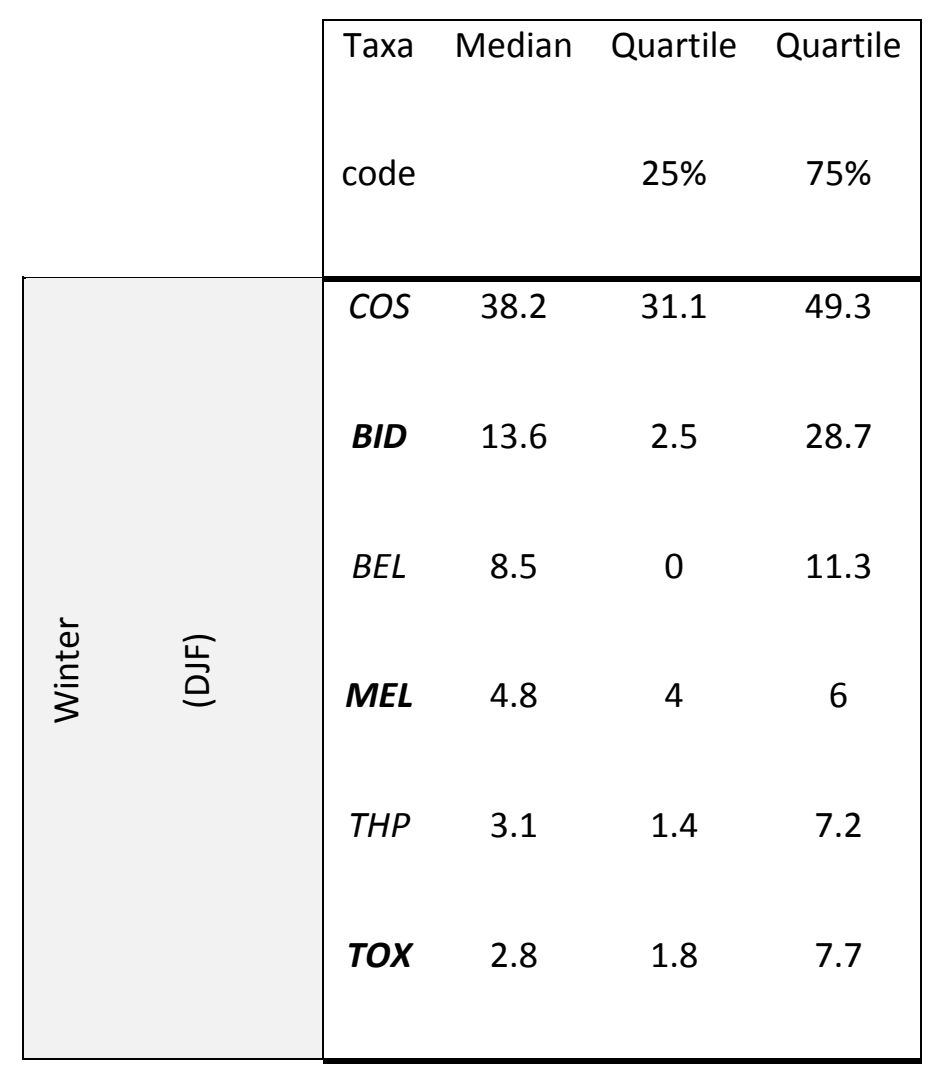

This article is protected by copyright. All rights reserved. 


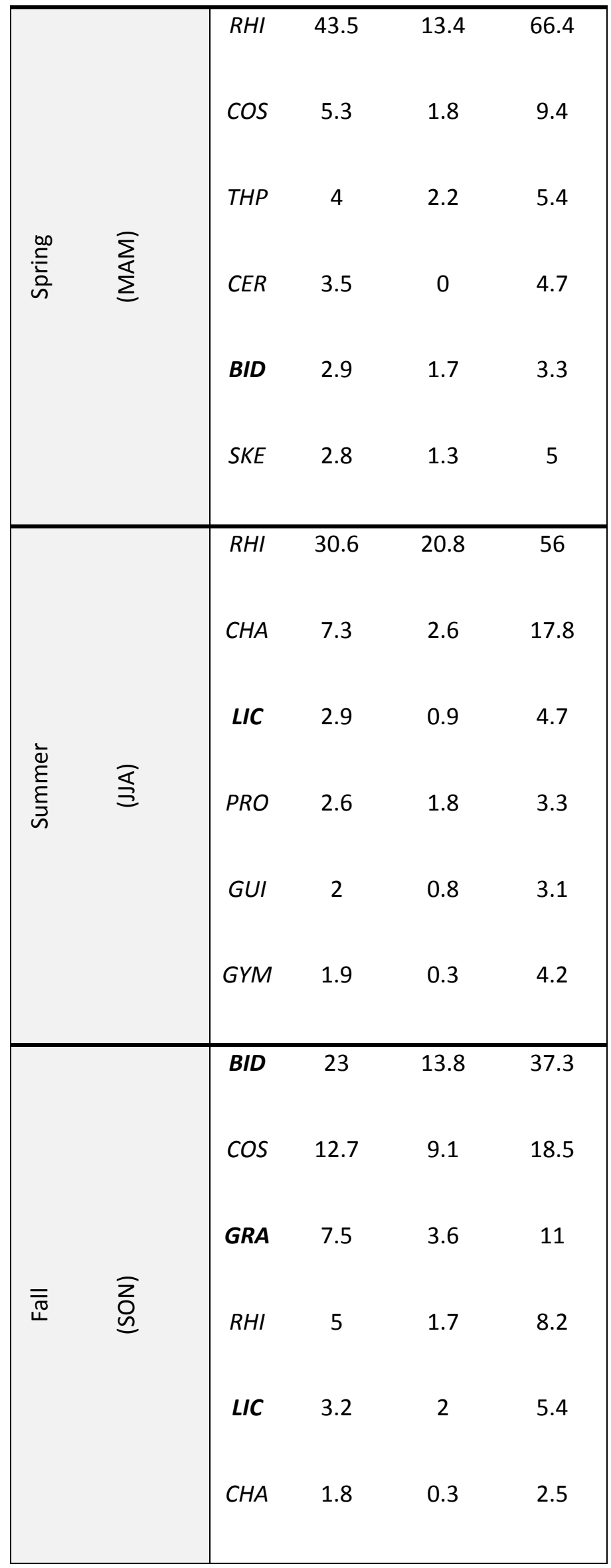

This article is protected by copyright. All rights reserved. 
Figure legends:

Fig. 1: Location of the sampling station (•) from the REPHY network analyzed in this study.

Fig. 2: Temporal variations (1995 - 2006) in in situ measurements of water temperature $\left({ }^{\circ} \mathrm{C}\right)$, salinity turbidity (NTU), chlorophyll- $a\left(\mathrm{Chl} a, \mu \mathrm{g} \cdot \mathrm{L}^{-1}\right)$ and "phytoplankton" total carbon biomass ( $\mathrm{g}$ Carbon $\cdot \mathrm{L}^{-}$ $\left.{ }^{1}\right)$. Data was represented at a bimonthly scale.

Fig. 3: Loire river flow $\left(\mathrm{m}^{3} \cdot \mathrm{s}^{-1}\right)$ and precipitation $(\mathrm{mm})$ data. For graphical representation, data were aggregated into monthly values.

Fig. 4: Proportion of benthic microalgae to the total microalgae carbon biomass. For graphical representation, data were aggregated into a monthly scale. Hence, monthly median values are represented. The box-and-whisker plot shows the median (horizontal line), the first and third quartile (box) and the last value within 1.5 times the interquartile distance (whisker) of the proportion of benthic microalgae recorded during the study period.

Fig. 5: Box-and-whisker plot of the growth forms carbon biomass between 1995 and 2006. The horizontal line denotes the median value, the box represents the first and third quartiles, and the whisker represents the last value within 1.5 times the interquartile distance. The $y$-axis is on logscale (base 10).

This article is protected by copyright. All rights reserved. 
Fig. 6: Time series of the growth forms carbon biomass (left panels) and the corresponding autocorrelation functions (right panels). The autocorrelation function was estimated based on the log-transformed (base 10) carbon biomass. Dotted lines on the autocorrelation functions represent the confidence interval.

Fig. 7: Seasonal component for each growth form obtained from the DLM model.

Fig. 8: Results from the co-inertia analysis. (A) Projection of samples described by the environmental datasets. Circles correspond to the barycentre (mean of sample projections) of classes at a bimonthly frequency representing a one-year cycle. The color gradient represents the seasons (from white to dark gray: winter $-W$, spring $-S P$, summer $-S U$ and fall $-F)$. (B) Projection of environmental variables. (C) Projection of taxonomic unit. Symbols represent the different growth forms: planktonic $\bullet$, tychoplanktonic $\mathrm{x}$, epipelic $\Delta$ epiphytic $\bullet$ and haptobenthic $\boldsymbol{m}$. For graphical representation, only labels of taxa with high scores on the first and second axis were added. Axes 1 and 2 represent $83.7 \%$ and $10.9 \%$, respectively, of the total variance. See Table 1 for taxa codes.

Figure S1: Year-to-year variation in the seasonality of the haptobenthic growth form obtained from the DLM model.

Figure S2: Proportion of benthic microalgae of the total abundance measured. For graphical representation, data were aggregated into a monthly scale. Hence, monthly median values are represented. The box-and-whisker plot shows the median (horizontal line), the first and third

This article is protected by copyright. All rights reserved. 
quartile (box) and the last value within 1.5 times the interquartile distance (whisker) of the proportion of benthic microalgae recorded during the study period.

Figure S3: Box-and-whisker plot of the growth forms abundance between 1995 and 2006. The horizontal line denotes the median value, the box represents the first and third quartiles, and the whisker represents the last value within 1.5 times the interquartile distance. The $y$-axis is on logscale (base 10).

Figure S4: Time series of the growth forms abundance (left panels) and the corresponding autocorrelation functions (right panels). The autocorrelation function was estimated based on the log-transformed (base 10) abundance. Dotted lines on the autocorrelation functions represent the confidence interval.

Figure S5: Seasonal component for each growth form obtained from the DLM model based on abundance data.

Figure S6: Results from the co-inertia analysis based on abundance data. (A) Projection of samples described by the environmental datasets. Circles correspond to the barycentre (mean of sample projections) of classes at a bimonthly frequency representing a one-year cycle. The color gradient represents the seasons (blue circles - winter, green - spring, orange - summer, violet - fall). (B) Projection of environmental variables. (C) Projection of taxonomic unit. Symbols represent the different growth forms: planktonic $\bullet$, tychoplanktonic $\mathrm{x}$, epipelic $\Delta$ epiphytic $\bullet$ and haptobenthic For graphical representation, only labels of taxa with high scores on the first and second axis were

This article is protected by copyright. All rights reserved. 
added. Axes 1 and 2 represent $84.6 \%$ and $11.1 \%$, respectively, of the total variance. See Table 1 for taxa codes.

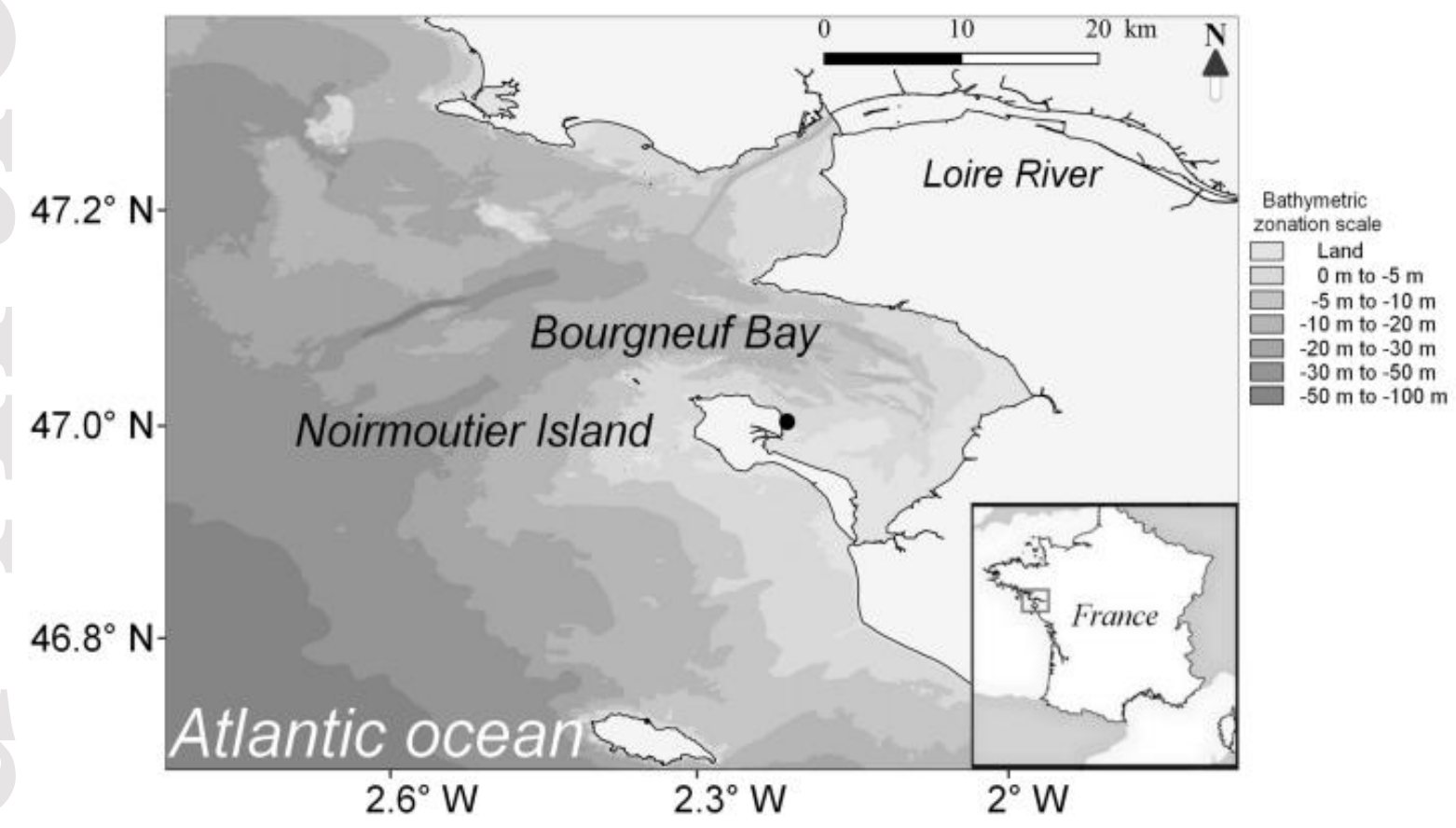

This article is protected by copyright. All rights reserved. 


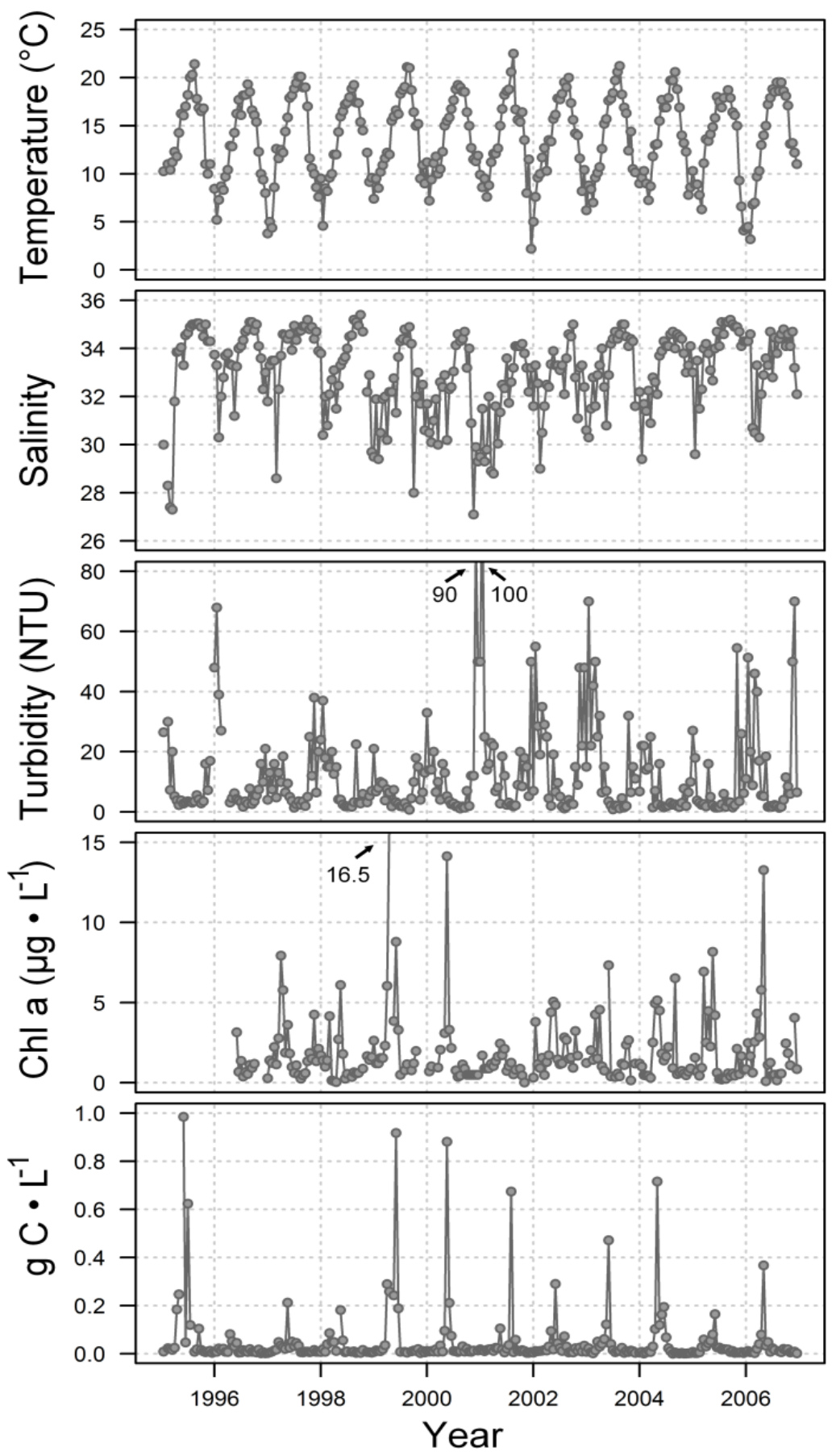

This article is protected by copyright. All rights reserved. 

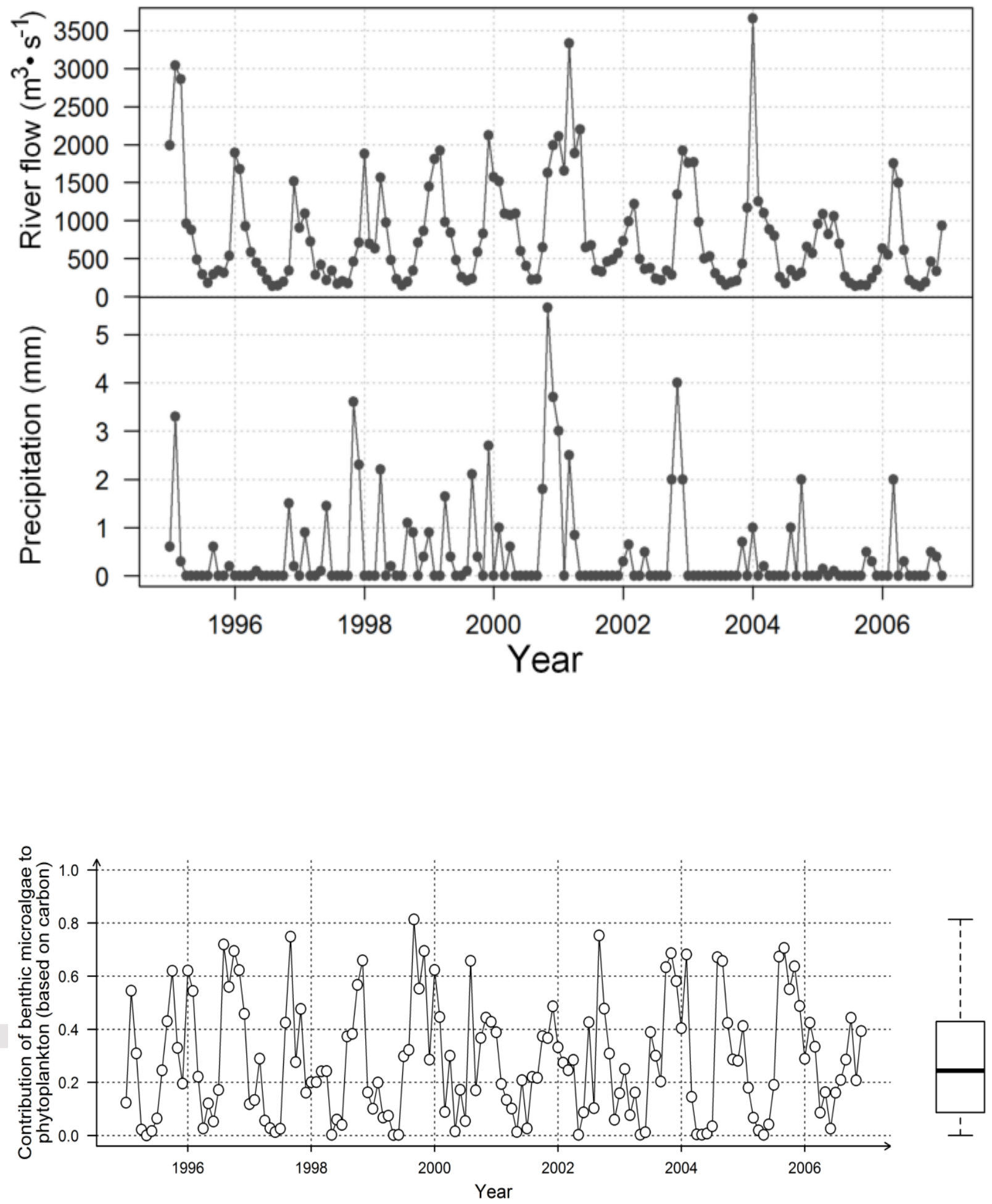

This article is protected by copyright. All rights reserved. 


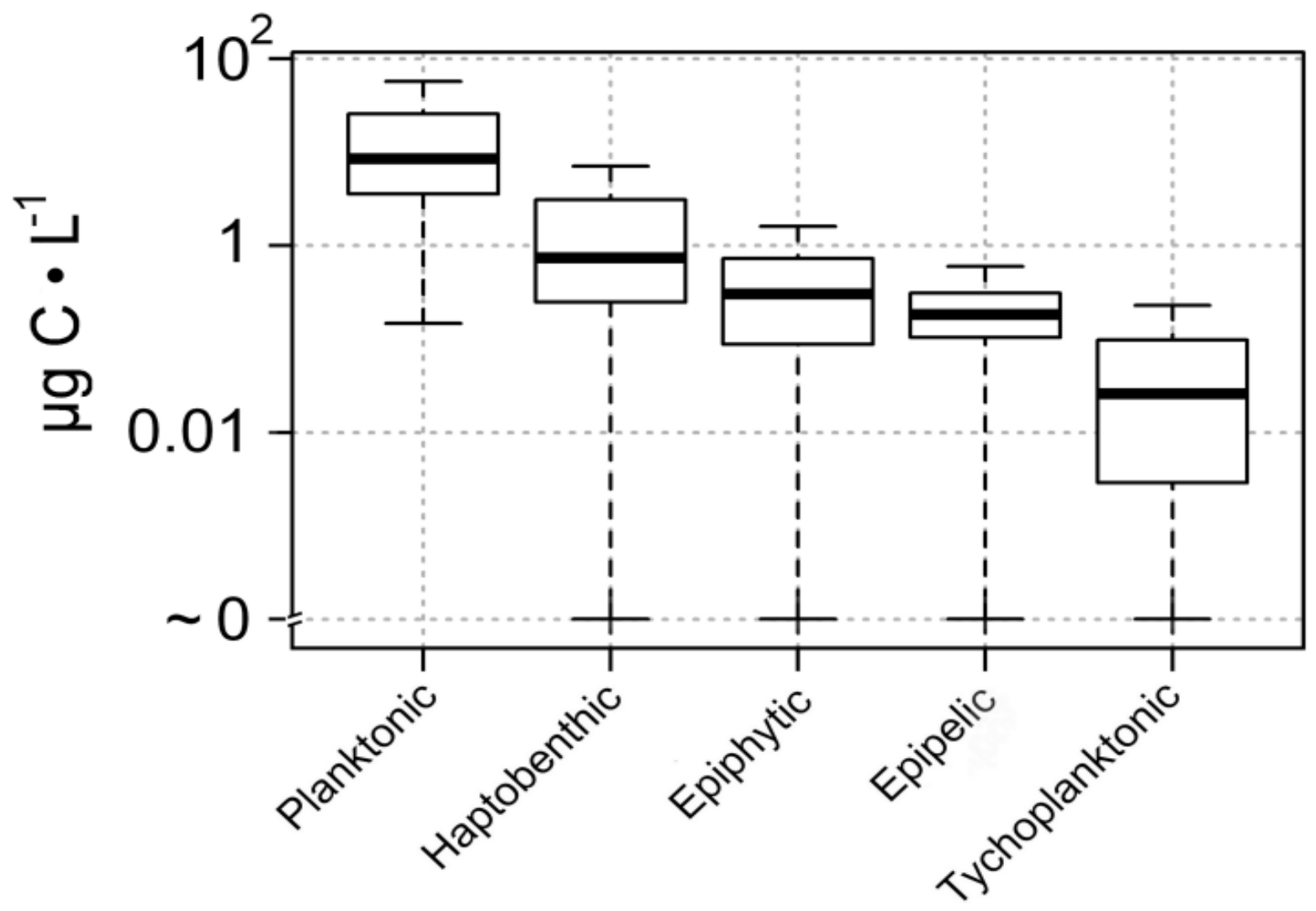

This article is protected by copyright. All rights reserved. 

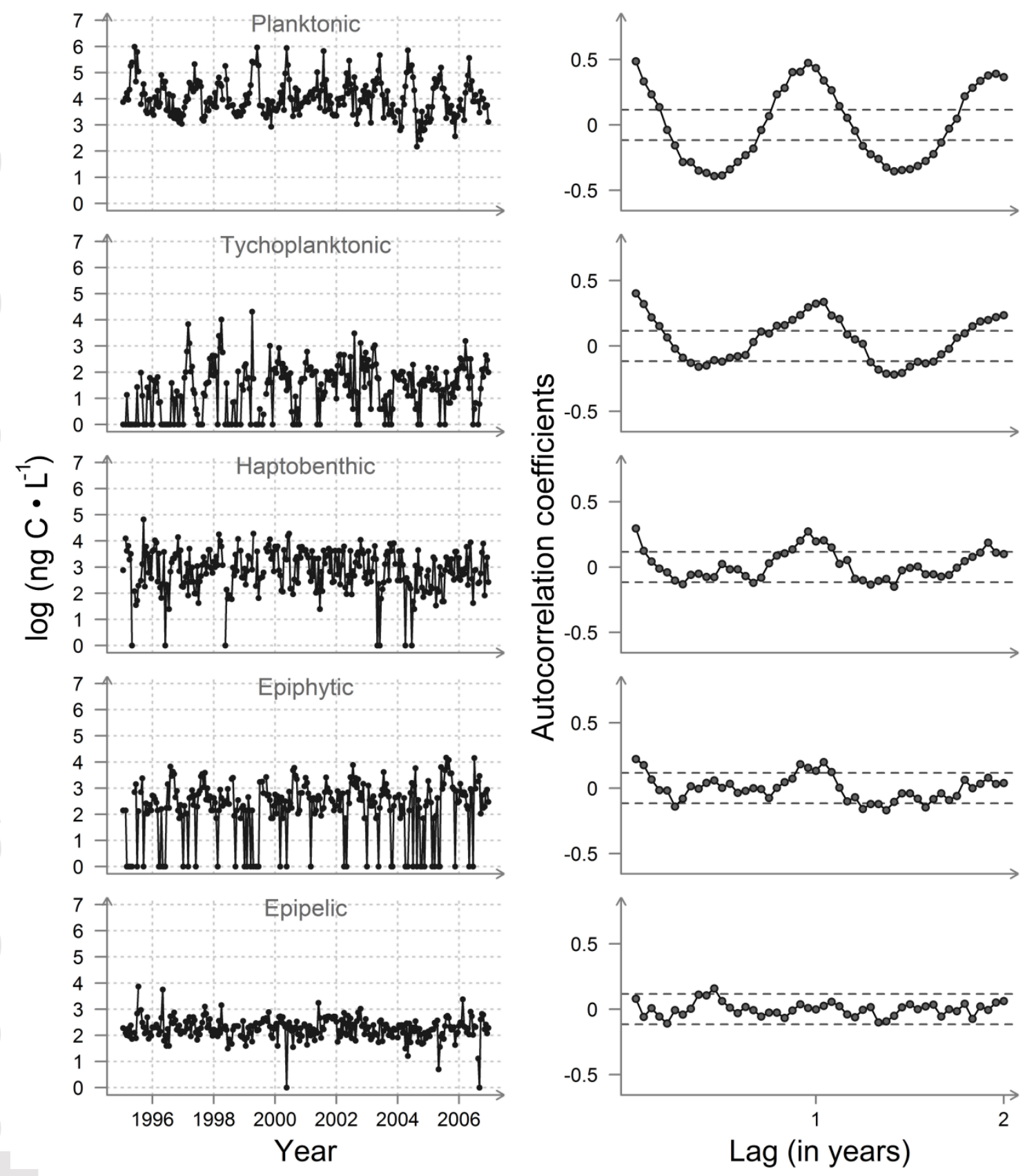

This article is protected by copyright. All rights reserved. 


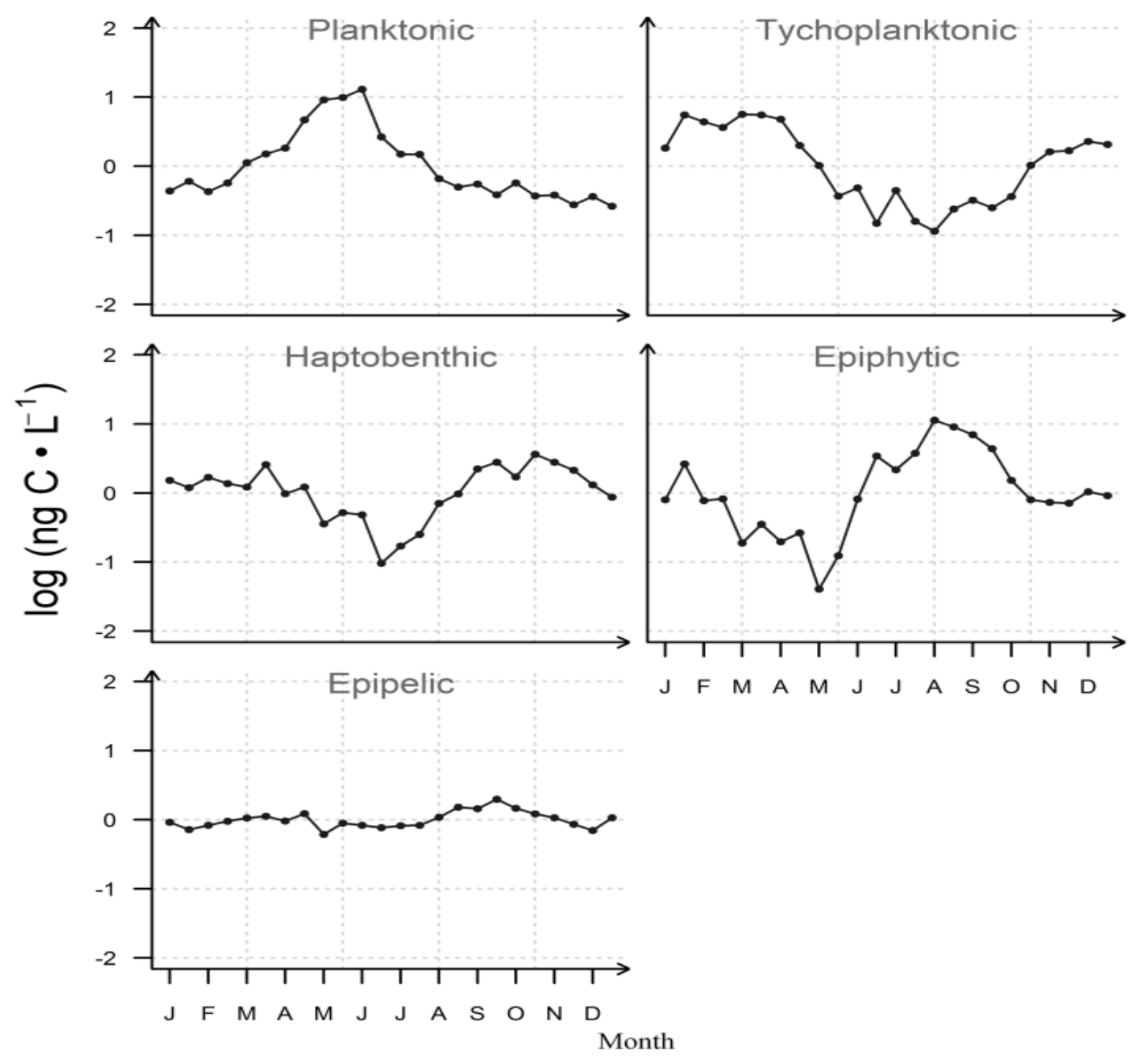

This article is protected by copyright. All rights reserved. 

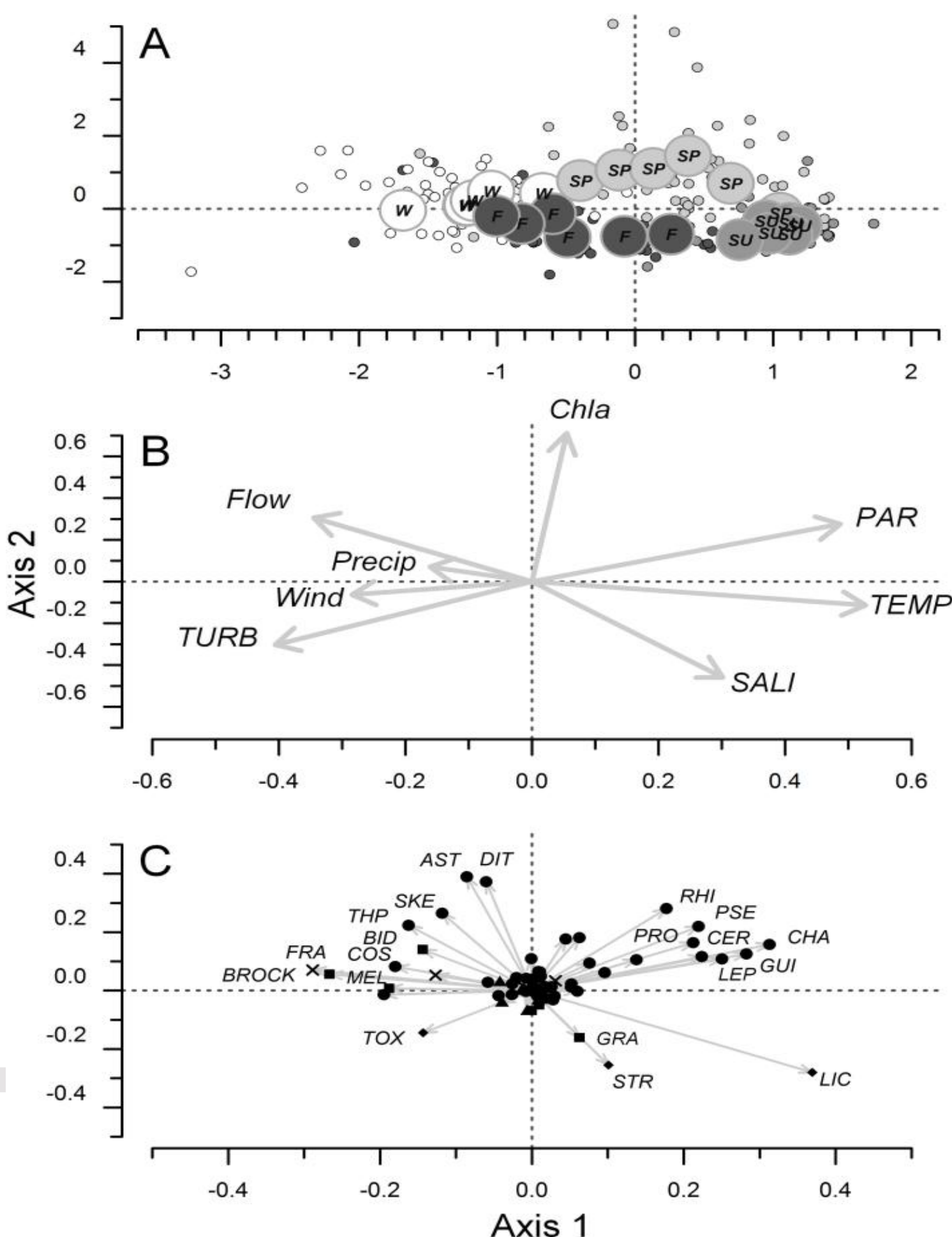

This article is protected by copyright. All rights reserved. 